\title{
THE ROYAL SITE OF SAN LORENZO DE EL ESCORIAL PROBLEMS, AREAS OF IMPROVEMENT AND SUSTAINABLE TOURISM DEVELOPMENT (PART 3)
}

\section{INTRODUCTION}

After having exposed and analyzed the current situation of tourism activity in San Lorenzo de El Escorial from information collected from various sources, the main problems will be identified to develop a diagnosis of tourism in the town. It is clear that these problems are an impediment to achieving sustainable tourism, and it is therefore necessary for the various competent authorities to address their resolution as soon as possible and with success. If this is not the case, there is a danger that its consequences will become chronic and that the survival of tourist activity in San Lorenzo de El Escorial will be endangered, as well as its current position as one of the most important tourist destinations in the Community of Madrid.

Thanks to the use of a series of diagnostic methods, it will be determined whether the current situation of tourism in San Lorenzo de El Escorial is a consequence of the problems detected. Those methods are:

- SWOT matrix ${ }^{1}$ : from which it will be possible to evaluate the positive and negative aspects of the case under study. This method was developed between the 1960s and 1970s at the Stanford University Research Institute by Albert S. Humphrey (1927-2005) $)^{2}$ to provide companies with an administrative system that would allow them to improve their planning. Thanks to this system, it is possible to analyze the internal aspects (strengths and weaknesses) and external aspects (threats and opportunities) of a project to determine its viability and establish adequate lines of action that allow to enhance its positive aspects and minimize the negative ones through adoption of modifications not initially contemplated.

- stakeholder mapping: it allows to graphically visualize the different participants in a project, as well as the relationships between them. It can undergo various

\footnotetext{
${ }^{1}$ https://en.wikipedia.org/wiki/SWOT_analysis (accessed May 2021)

2 https://en.wikipedia.org/wiki/Albert_S._Humphrey (accessed May 2021)
} 
modifications during the development of a project, such as the addition or deletion of actors or some of their relationships.

- DPSIR ${ }^{3}$ : this indicator model, proposed in 1998 by the European Environment Agency, is considered an extension of the PSR model presented by the OECD in 1991. It serves to determine the interactions and consequences of various human activities on the environment and to devise and implement actions to reduce or avoid its effects.

- a system of indicators: a set of various values from which it is possible to obtain relevant information on certain aspects in order to subsequently analyze and evaluate them. By using it, it is possible to avoid measures that could jeopardize the viability of a project.

\section{ESSENTIAL PROBLEMS IN THE DESTINATION}

According to the data obtained and its subsequent analysis, the main problems that condition the sustainable development of the tourism in San Lorenzo de El Escorial are the following:

- cleaning and urban maintenance: this is one of the problems that generates the most criticism and discomfort among residents and tourists ${ }^{4,5}$, as can be inferred from the analysis of the information collected from various media and from the field work ${ }^{6}$ carried out. Urban cleaning and maintenance in San Lorenzo de El Escorial are far from what an important tourist destination should have with regional, national and international recognitions such as UNESCO World Heritage Site. The current municipal government team has expressed, according to the information provided, its willingness to solve this problem as soon as possible ${ }^{7}$. According to this information, at the end of October 2019 the first phase

\footnotetext{
${ }^{3}$ https://servicio.mapama.gob.es/sia/indicadores/modelo.jsp (accessed May 2021)

${ }^{4}$ https://aquienlasierra.es/san-lorenzo-de-el-escorial/la-limpieza-viaria-aspecto-mas-cuestionadolosvecinos-san-lorenzo-la-primera-encuesta-satisfaccion-realizada-ayuntamiento/36962/

${ }^{5}$ https://aquienlasierra.es/san-lorenzo-de-el-escorial/cartas-de-los-lectores-el-estercolero-de-laplazade-las-animas-en-san-lorenzo-de-el-escorial/40940/ (accessed June 2021)

${ }^{6}$ It is recommended to view the photographic dossier previously provided to verify the current status of various parts of the municipality.

${ }^{7}$ https://aquienlasierra.es/san-lorenzo-de-el-escorial/la-alcaldesa-de-san-lorenzo-fija-como-prioridadlapuesta-en-marcha-de-un-plan-de-choque-en-materia-de-limpieza/44521/ (accessed June 2021)
} 
of an ambitious cleaning plan was completed, which is currently continuing in a second, budgeted at $€ 13,000^{8}$ and which began last November ${ }^{9,10}$. Likewise, the city council is studying the possibility of extending the cleaning plan throughout the year and approving a municipal ordinance on this matter, in addition to starting a public awareness campaign ${ }^{11}$.

- shortage of parking and its high price: along with the previous one, it is another problem that causes the highest number of complaints from residents and visitors $^{12}$. In part it is a consequence of the urban structure and orography of the municipality, characterized by narrow streets and slopes that in some points reach a slope of $13 \%$. In addition, in recent years, successive municipal government teams have increased the area of special pricing areas (blue zone), which, in addition to the excessive prices for parking, continue to be criticized. The lack of parking spaces causes, especially during weekends and holidays, major traffic jams in various areas of the town, such as Plaza de la Virgen de Gracia and Avenida de Juan de Borbón y Battenberg. As a consequence of this, it is common to observe numerous vehicles parked on the sidewalks, causing defects in urban elements, in addition to preventing pedestrian traffic. Although there are some privately managed public car parks such as those on Rey ${ }^{13}$ and Floridablanca ${ }^{14}$ streets, none have a good reputation among visitors, as can be read in their reviews, where they show their discontent due to the excessive price, lack of security and the poor cleanliness and condition of its facilities. Likewise,

\footnotetext{
${ }^{8}$ https://www.cope.es/emisoras/comunidad-de-madrid/madrid-provincia/villalba/noticias/planchoquelimpieza-cumple-mes-20190805_474056 (accessed June 2021)

${ }^{9}$ https://www.aytosanlorenzo.es/servicios/medio-urbano/plan-de-limpieza-de-san-lorenzo-deelescorial/ (accessed June 2021)

${ }^{10}$ https://www.lavanguardia.com/vida/20191108/471450185247/san-lorenzo-de-el-escorial-inicialasegunda-fase-de-su-plan-de-limpieza.html (accessed June 2021)

${ }^{11}$ https://aquienlasierra.es/san-lorenzo-de-el-escorial/plan-integral-limpieza/57324/ (accessed June 2021)

12 https://aquienlasierra.es/san-lorenzo-de-el-escorial/la-limpieza-viaria-aspecto-mas-cuestionadolosvecinos-san-lorenzo-la-primera-encuesta-satisfaccion-realizada-ayuntamiento/36962/ (accessed June 2021)

${ }^{13} \mathrm{https}$ ://www.google.com/search?q=aparcamiento+monasterio\&rlz=1C1AVFC_enES782ES782\&oq=apa rcamiento+monasterio+\&aqs=chrome.69i57j017.9469j0j4\&sourceid=chrome\&ie=UTF8\#Ird=0xd410a258f5ee5f1:0x8f9136a4667c78be,1,,, (accessed June 2021)

${ }^{14}$ https://www.google.com/search?q=Parking+P\%C3\%BAblico+BENCAR+EGS\&rlz=1C1AVFC_enES782ES7 82\&oq=Parking+P\%C3\%BAblico+BENCAR+EGS\&aqs=chrome..69i57.396j0j9\&sourceid=chrome\&ie=UTF$8 \# \mid r d=0 x d 410 a 28816 b f 15 d: 0 x a 7 a d 8 f 69 a 5 f 71426,1,$, (accessed June 2021)
} 
measures such as the charging of parking for "zero emissions" vehicles do not help to alleviate the problem ${ }^{15}$.

- lack of institutional cooperation: for too many years, the lack of understanding between municipal governments and the National Heritage continues to be a significant impediment to promoting actions that can minimize some problems. Paradoxically, when both entities have collaborated, the results have been satisfactory. Unfortunately, this lack of cooperation is also spreading in the relationships that the town council maintains with the Community of Madrid, responsible for the management of places such as the Real Coliseo de Carlos III or the Theater-Auditorium of San Lorenzo de El Escorial, underused since its inauguration in $2006^{16}$ and which continues to generate controversy due to the large economic investment (more than $€ 70$ million $^{17}$ ) that was made. It is also worth mentioning the disagreement between the city council and local business associations such as Restaura Escorial ${ }^{18}$ and ASLEPYME ${ }^{19}$, which is affecting the proper development of tourism.

- underutilization of tourist resources: the area of San Lorenzo de El Escorial that supports greater tourist pressure is comprised of the Royal Monastery and its closest surroundings (Avenida de Juan de Borbón and Battenberg) and Floridablanca, del Rey and Duque de Alba streets, as well as the Plaza de la Constitución. Meanwhile, other areas with interesting tourist resources are ignored by most of the visitors. San Lorenzo de El Escorial has an exceptional environment that, with the exception of La Herrería, is not being used, except for some testimonial private initiatives. The current tourist model of the municipality, based almost exclusively on the visit to the Royal Monastery complex, shows clear signs of exhaustion due to the proximity of other destinations with a similar

\footnotetext{
${ }^{15}$ https://www.evpro.es/coches/san-lorenzo-de-el-escorial-abre-el-debate-tambien-cobra-poraparcara-los-vehiculos-con-etiqueta-cero/ (accessed June 2021)

${ }^{16} \mathrm{https}: / /$ www.beckmesser.com/el-teatro-auditorio-de-san-lorenzo-de-el-escorial-detras-del-telon-2/ (accessed June 2021)

17 https://www.20minutos.es/noticia/1738148/0/expropiacion-escorial/gallardon/condena-madrid/ (accessed June 2021)

18 https://aquienlasierra.es/san-lorenzo-de-el-escorial/restaura-escorial-acusa-al-ejecutivo-sanlorenzodespreciar-la-hosteleria-califica-despectivo-trato-recibe-la-asociacion/31917/ (accessed June 2021)

${ }^{19}$ https://www.elfarodelguadarrama.com/noticia/46895/san-lorenzo/la-aslepyme-pidealayuntamiento-de-san-lorenzo-potenciar-el-comercio-.html (accessed June 2021)
} 
or even greater tourist offer (Toledo, Avila, Segovia, Aranjuez and Madrid). The lack of alternatives that motivate successive visits to the municipality means that the level of overnight stays does not rise. Although efforts are being made to diversify the tourist offer of San Lorenzo de El Escorial and adapt it to the new demands of visitors, there is still much to do.

- tax pressure: although it is not strictly a tourist issue, its effects are felt very significantly. The high level of taxation by the different municipal governments has caused in recent years a constant increase in local taxes, which have increased the prices of goods and services offered to visitors, which in some cases discourages second visits and a containment of the spending by tourists. The concern is clear among businessmen in the tourism sector, whose situation, in some cases is extremely difficult, and more since the 2008 crisis, whose consequences can be clearly seen in the decline of one of the most important shopping streets in San Lorenzo de El Escorial, Las Pozas, whose state of neglect is constantly denounced in the media. In order to revitalize local business activity, the municipal government approved a "zero quota" 20 aimed at new entrepreneurs which, according to conversations with members of business associations such as Restaura Escorial or ASLEPYME, is insufficient. Instead, they propose a reduction of taxes and fees, which curiously were part of the electoral program of the present municipal government ${ }^{21,22}$ and which have not yet been carried out.

\section{DIAGNOSIS OF TOURISM IN THE DESTINATION}

As in other Royal Sites, San Lorenzo de El Escorial has a heritage that differentiates it from other destinations, not only in the Community of Madrid, but in the rest of Spain. It is one of the most prominent and consolidated destinations, both regionally and nationally, and that attracts the most visitors. However, there are several structural

\footnotetext{
${ }^{20}$ https://aquienlasierra.es/san-lorenzo-de-el-escorial/cuota-cero-emprenedores/49482/ (accessed June 2021)

${ }^{21}$ https://www.lavanguardia.com/local/madrid/20171010/431956470213/el-equipo-de-gobierno-deelescorial-propone-bajar-los-impuestos-en-2018.html (accessed June 2021)

22 https://aquienlasierra.es/san-lorenzo-de-el-escorial/el-pp-de-san-lorenzo-de-el-escorial-presentaunacandidatura-con-una-amplia-renovacion-de-cara-a-las-municipales-del-26-m/42015/ (accessed June 2021)
} 
problems that, if not addressed seriously, could become a serious impediment to the future development of tourism in the municipality.

Added to the problems identified are other factors such as the proximity of an important destination such as the city of Madrid, a greater diversification of demand or the exhaustion of the tourist model of San Lorenzo de El Escorial, based almost exclusively on the visit to the Royal Monastery. All of these are more than enough reasons to consider the reformulation of municipal tourism management and a new tourism model that allows San Lorenzo de El Escorial to remain as one of the most important tourist destinations in the Community of Madrid and the country. It is undeniable to question that the monastic complex of San Lorenzo de El Escorial is an undeniable tourist attraction, which by itself is capable of attracting around 500000 tourists per year, but more and more visitors are looking for other motivations to go to the locality such as, for example, enjoying a pleasant urban environment that, due to the lack of maintenance and cleaning, is not as well cared for as it should be. This problem, like the shortage of parking, should be the first to be solved. If they are ignored, the future of tourism in the municipality may be in danger. If San Lorenzo de El Escorial wants to maintain and improve its position as a tourist destination, it must have a new suitable tourist model that allows it to attract new visitors, extend their stay through the creation of new tourist products and the improvement of existing ones, as well as the enhancement of currently underused resources.

It is important to take into consideration that the most outstanding heritage of San Lorenzo de El Escorial, the Royal Monastery, is not directly managed by the city council, but rather depends on the National Heritage, an independent public body with its own legislation and objectives that have little to do with those of the municipality, and conditions the local tourism development and the measures to be applied. Despite this, San Lorenzo de El Escorial has other heritage and natural attractions that can become an excellent complement to the monastic complex, or even become the main attraction for many visitors.

The current lack of a Tourism Excellence Plan like the one the municipality had between 2003 and 2006 and which, unfortunately, did not have continuity, allowed to undertake several actions to improve the tourist development of San Lorenzo de El Escorial. Among the results of that plan is the Local Tourism Office, but other measures that could have 
avoided some current problems could not materialize as a result of the economic crisis of 2008, whose effects still persist, among other places, in Las Pozas ${ }^{23}$.

Although the new municipal government seems to have become aware of the need to solve these problems, there is still much to do, and time will tell if it only remains as good intentions or, on the contrary, it can be solved.

\section{CONCLUSION}

Briefly, if San Lorenzo de El Escorial wants to maintain its position as one of the most significant tourist destinations in the Community of Madrid and Spain, it is necessary to solve the problems detected and rethink the viability of its current tourism model to guarantee its future sustainability. For this, it is necessary to obtain the cooperation of all the agents involved, whether they are public or private, to guarantee the achievement of the following objectives:

- get visitors to extend their visit, and thereby increase overnight stays.

- diversify the tourist offer to adapt it to current demands and open up to new markets.

- promote other tourist attractions in the municipality to relieve the pressure that is concentrated in a very specific area, and generate successive visits by enhancing these resources and other events that attract visitors, and that are also capable of guaranteeing the sustainability of tourism in the town and its heritage.

- establish an urban maintenance and cleaning program that, according to what is expressed by the current municipal government, seems to be underway, but due to the situation derived from the current COVID-19 pandemic, it has been put on hold.

\footnotetext{
${ }^{23} \mathrm{https}$ ://aquienlasierra.es/san-lorenzo-de-el-escorial/cartas-de-los-lectores-el-ocaso-de-lacallepozas/39993/ (accessed June 2021)
} 


\section{BIBLIOGRAPHY}

- Calle Vaquero, M.; García Hernández, M. (1998) Ciudades históricas: patrimonio cultural y recurso turístico; Ería, $n^{\circ} 47,249-266$

- Celdrán Bernabeu, M.A. (2014) "Estrategias y políticas de turismo sostenible" in Canyelles i Pastó, J.M.; Celdrán Bernabeu, M.A.; Grünig Iribarren, S. \& March Corbella, H.; Sostenibilidad y turismo, Barcelona: Oberta UOC Publishing

- Comisión Europea (2017) El sistema europeo de indicadores turísticos: herramienta del ETIS para la gestión de destino sostenibles, Oficina de publicaciones de la Unión Europea

- García Hernández, M.; Mínguez García, Ma C. (2005) Funcionalidad turística de los Reales Sitios Españoles: problemas y perspectivas; Ería, $n^{\circ} 66,71-84$

- Mínguez García, Ma C. (2007) Planificación y Gestión Turística en destinos patrimoniales: el caso del Real Sitio de San Lorenzo de El Escorial (Comunidad de Madrid); Anales de Geografía, vol. 27, $n^{\circ}$ 1, 83-102

- OECD (2003) Environmental indicators: development, measurement and use, OECD Environment Directorate (Environmental Performance and Information Division), Paris.

- OMT (2005) Indicadores de desarrollo sostenible para los destinos turísticos: guía práctica, Organización Mundial del Turismo, Madrid

- Rivas García, J. \& Magadán Díaz, M. (2007) Los indicadores de sostenibilidad en el turismo; Revista de economía, sociedad, turismo y medio ambiente RESTMA, $n^{\circ}$ 6, 27-61

- Troitiño Vinuesa, M.A.; Calle Vaquero, M.; García Hernández, M.; Troitiño Torralba, L. (2005) La funcionalidad turística del patrimonio cultural (B.I.C.) de la Comunidad de Madrid y estrategias de actuación; Dirección General de Turismo (Consejería de Economía e Innovación Tecnológica Comunidad de Madrid) 
- Velasco González, M. (2009) Gestión turística del Patrimonio Cultural: enfoques para un desarrollo sostenible del turismo cultural; Cuadernos de Turismo, $n^{\circ} 23,237-253$

- $\quad$ Vera, J.F. (Dir.), Juárez, C., Morte, A., Torres, F., Navalón, M., Such, Ivars, J.A. (2001). Planificación y gestión del desarrollo turístico sostenible: propuestas para la creación de un sistema de indicadores. Alicante: Instituto Universitario de Geografía, Universidad de Alicante.

- Vera, J.F., Ivars, J.A. (June 2004). Indicadores de sostenibilidad turística para destinos maduros: balance y propuesta de aplicación. Comunicación presentada en la conferencia de la Organización Mundial del Turismo: Creando estructuras para la Investigación y la Educación en Política Turística y Gestión de Destinos, Madrid: Spain.

\section{ANNEXES}

\section{TRAFFIC JAM AREAS IN SAN LORENZO DE EL ESCORIAL}

\section{A. Plaza de la Virgen de Gracia}

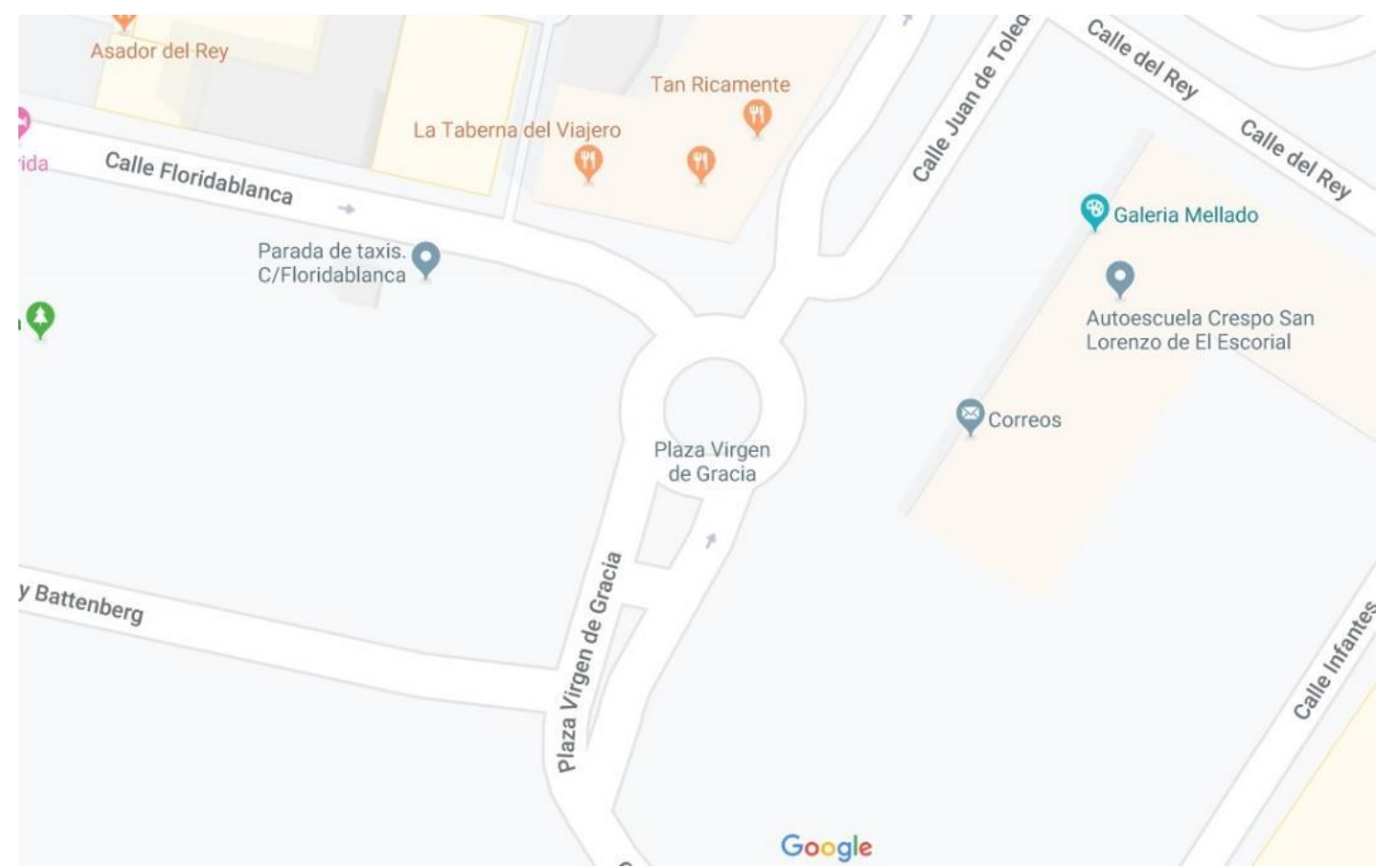



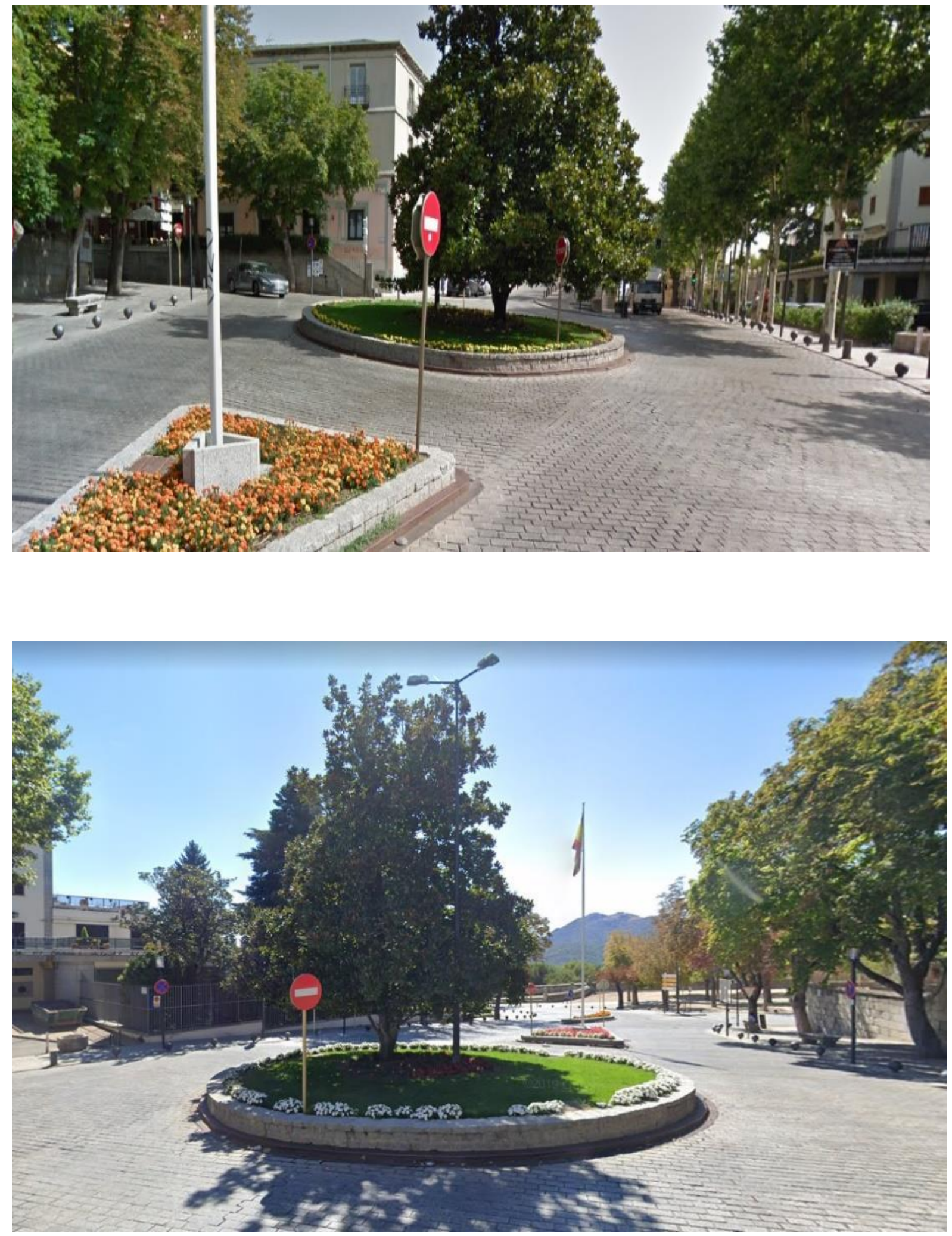
(C) Mario Martín Merino, 2021

\section{B. Juan de Borbón y Battenberg Avenue}
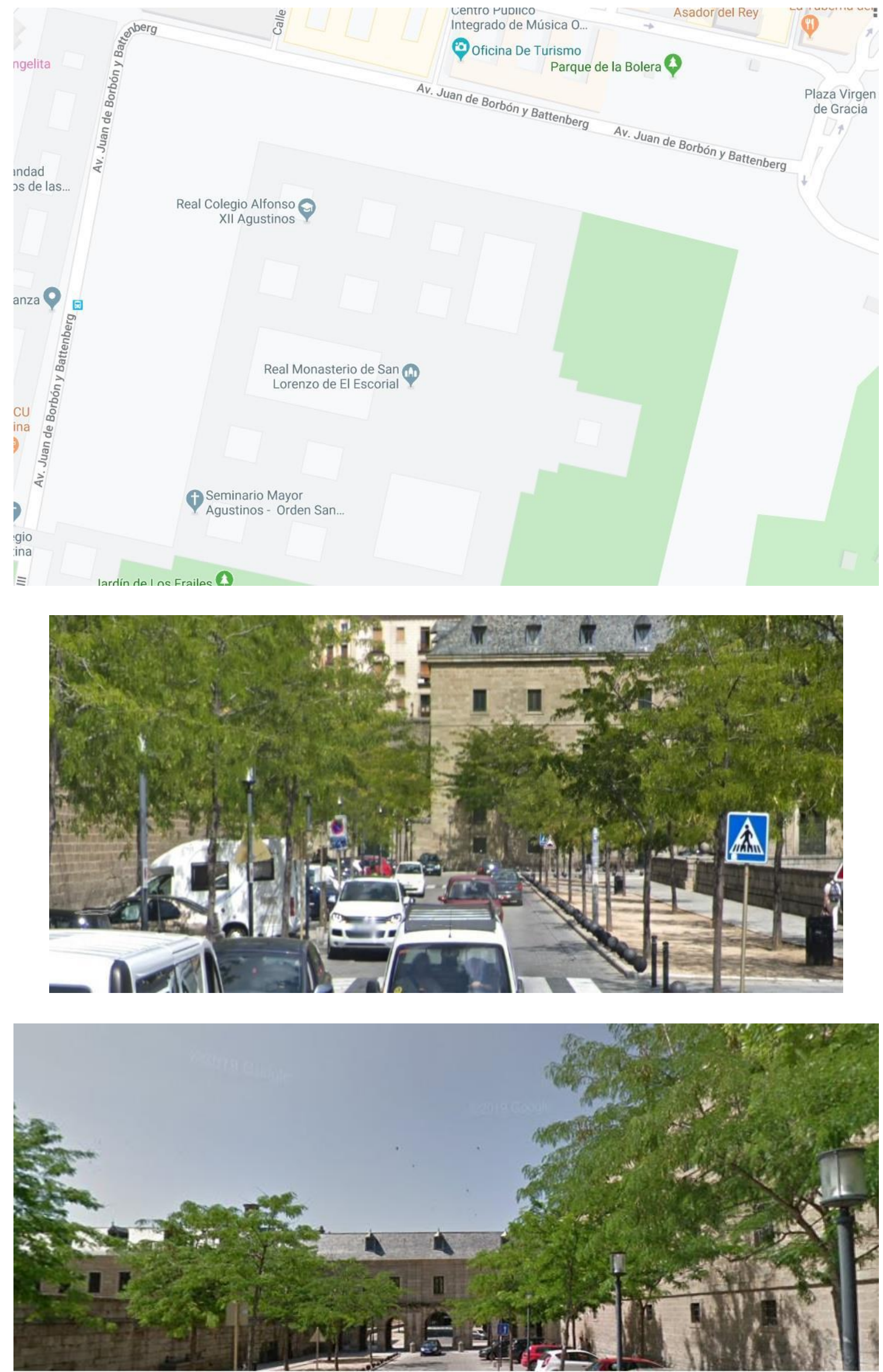


\section{LAS POZAS}

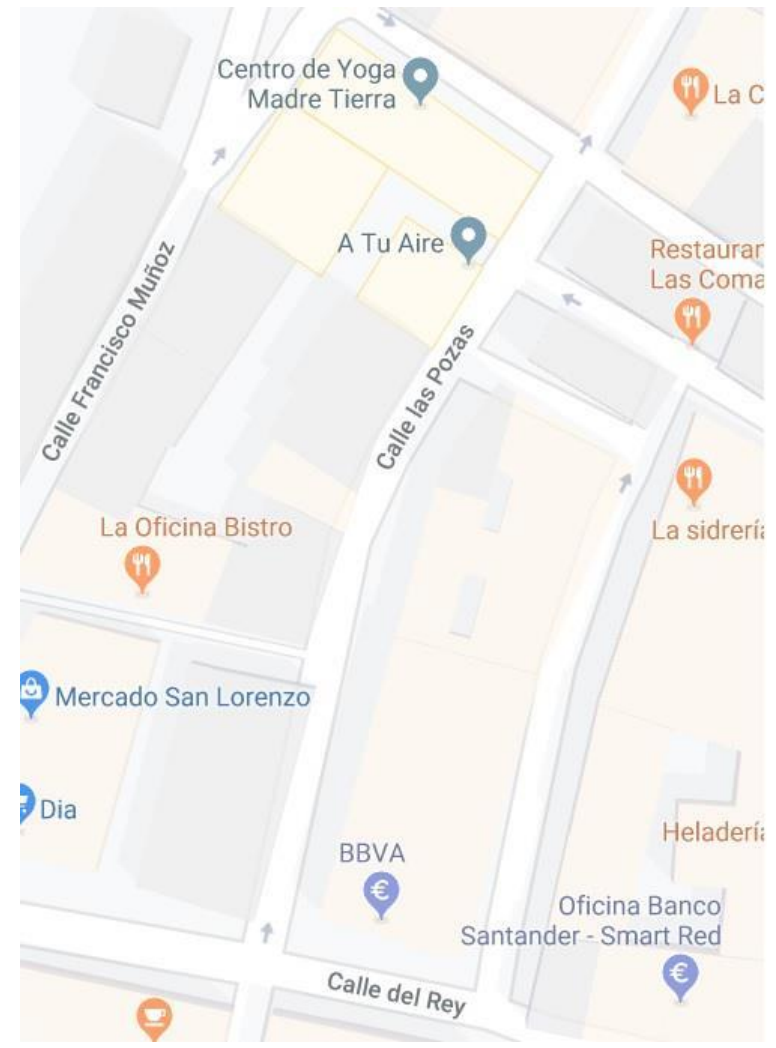

\section{TOURIST PRESSURE ZONE}

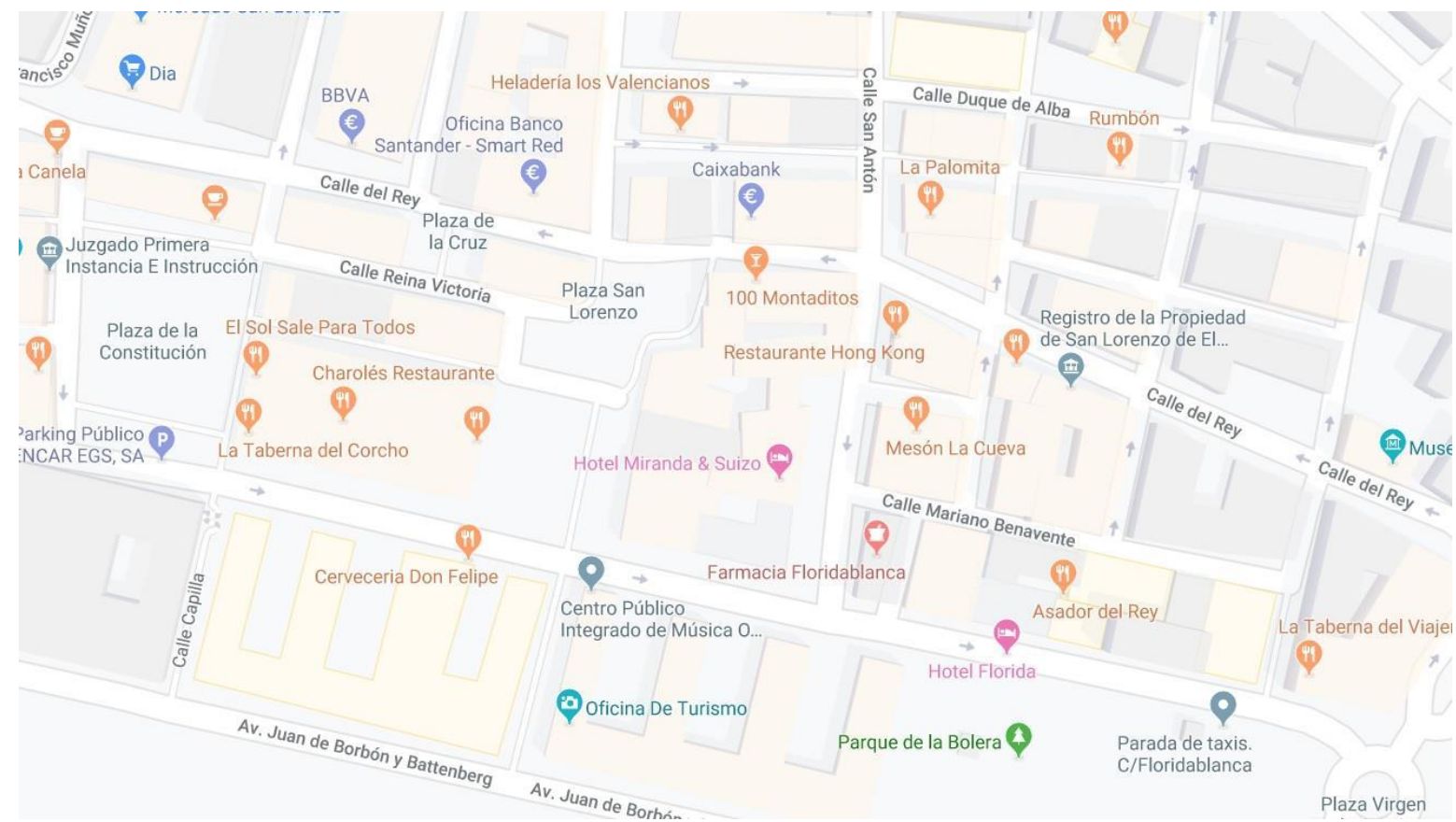

